要である。

以上，気の付くことを述べてきたが，使用す る側にも問題がある。今までは使用する側と作 る側との討論が少なく，今後はより現場に則し た，看護部門，パラメディク部門等の意見も取
り入れた，使用しやすく，統一性を考えた機器 の開発が必要であると思われる. しかし臨床の 基本は，患者を見，音を聞き，触る，すなわち， 視診, 聴診, 触診であり,このことを，使用す る側も作る側も忘れてはならない。

\title{
3. 医療器機の有用性と看護婦の役割り
}

医学の進歩とともに, 各種のモニタや診断治 療器機が製品化され，一般病棟においても患者 の治療および看護にとって必須のものとなって いる.したがって看護婦にとってもこれら医療 器機についての知識を習得し, 安全かつ正確な 操作に熟達することが要求される，今回，国立 循環器病センター看護婦 300 名に日常よく使用 している医療器機についてアンケート調査を行 い，医療器機使用にあたっての看護上の役割お よび医療器機に対する知識, 管理, 保守に関し ての問題点を整理した.

医療器機が看護上どのような点に役立ってい るかについては，異常の早期発見に役立ってい ると解答した看護婦が全体の $34 \% を$ 占めていた。 これはセンターの特殊性から全病棟に患者監視 装置が設置されていること，狭心発作や，心笳 梗塞のリハビリテーション等に際し看護婦が心 電図を記録していることなどによるものと思わ れる. 次に $24 \%$ 看護婦が業務の省力化をあげ ている. 具体的には自動輸液装置使用による点 滴管理の簡易化, 自動血圧計による継続的な血 圧チェック等である。また血管拡張剤や，カテ コールアミン等微量で強力な作用をもつ薬剂使 用に対し持続注入器により正確な与薬ができる と答えた看護婦が $20 \%$ ，薬剤の効果判定に役立 つと答えた看護婦が $12 \%$ ，患者の苦痛の軽減お よび看護レベルアップに役立つと答えた看護婦 は，それぞれ $5 \%$ と $2 \%$ とあった。医療器機使
国立循環器病センター

斉藤 貞子

用に際しての教育については, 経験 6 年未満の 看護婦では同僚による説明が大部分を占めてお り，6年以上の看護婦では同僚と業者による説 明が同程度みられた。新採用者教育の一環とし て医燎器機についての説明とデモンストレーシ ヨンがなされているためと思われた医療器機取 り扱い説明書については，90\%の看護婦が目を 通していることがわかった。しかし取り扱い説 明書の理解度については，少しわかると答えた 看護婦が $6 \%$ 以上占めており, 理解できない理 由として，“英文でわかりにくい”が最も多かっ た．また“説明がわかりにくい”と答えた看護 婦も少なくなく説明書の内容は, 必ずしも十分 とはいえないと考えられた. 医療器機習熟につ いては, 過半数の看護婦が 1 力月以内に習熟で きていた.しかし呼吸器の習熟には 6 力月〜 1 年を要していることがわかったまをた医療器機 使用中の患者を看護する上にどのような点に注 意しているかをみると, 器機が設定どおりに正 確に働いているかどうかに注意をはらっている と答えた看護婦が23\%, 器機が作動しているか どうかが $7 \%$ ，患者に説明を十分にし不安の軽 減につとめるが $21 \%$, 患者の安全に注意するが $9 \%$, 患者の苦痛の軽減につとめるが $8 \%$, 器 機に頼らず実際に確認すると答えた看護婦が 14 \%みられた. 経験年数別に医療器機使用に伴う 失敗例をみると, 3 年末満の看護婦では, スイッ チの入れ忘れ，ダイヤル設定のあやまり，組みた 
てのあやまり等の初歩的なものが多く，3年以 上の看護婦では，操作のあやまり，点検もれ等 いわゆる“なれ”によると思われるものが多か った。器機別では持続注入器が最も多く $81 \%$ を 占めていた，患者の苦情については，騒音によ る苦痛，不眠が $60 \%$ を占めて损り，その他，行 動範井，体動制限等による苦痛であった。器機 別には持続注入器が $68 \%$, 次いで持続血圧計, 患者監視装置であった。医療器機を実際に使用 して業務を行っている現場の看護婦がこ饥らの 器機のどのような点に問題を感じているかまと めると次の 9 項目がその主なものであった１. 器械の小型および軽量化，2. 器械作動音の弱 音化，3．器械の故障が多い，4. 器械操作の単
純化, 5. 器械各部分の名称の日本語による表 示，6. 七ット類の統一，7. 破損しやすい部品 のスペアが欲しい，8. 固定支柱の改良，9. 自 動血圧計の值の正確性, 以上のことより次の結 果を得た。1.医䝤器機使用は, 異常の早期発見, 業務の省力化等に役立っていると感じている看 護婦が多くみられた，2. 医䝤器機使用法の説明 は，ほとんどが同僚看護婦よりなされていた， 3. 呼吸器以外の器機では, 過半数の看護婦が 1 力月以内に習熟できていた，4. 医䝤器機使用に あたっては説明を十分に行い患者の不安，苦痛 の軽減につとめることが大切であると考えられ た，5. 患者および使用者の側にたった改善が望 まれる点も少なくなかった。

\title{
4. N IC Uにおける看護の現状と問題
}

\author{
大阪府立母子保健総合医療センタ一周産期 2 部新生児棟
}

横尾京子

\section{はじめに}

この10数年間における周産期医燎の進歩はめ ざましく, 現在ではN I C Uが整備され, 重症 仮死児や極小未熟児に対しても医療内容は洗練 化され，その結果 intact survival への期待が 可能となった。しかしそれと同時に一方では， non or less invasive care や quality of life が 強調され，高度医療技術によるケア内容をいか に humanizeするかが問われるようになってき た。このようなN I C Uに扔ける臨床背景をも とに, 医療機器を駆使した看護にお㧍現状と 問題点を検討したい。

\section{1. 新生児・未熟児のモニタリングと観察}

新生児・未熟览の病態変化は極的て早く, subtle sign レベルでの異常の早期発見が急性 期の救命および安定化に汇重要である. 今日, N I C U では呼吸循環系の監視装置は，医師の 綿密な診察や看護観察同様, その意義は大きく 一般化されている。しかし問題が残っている.
1）呼吸心拍と stateの関係

呼吸・心拍に関して乳幼览や成人と異なる点 は，新生児の場合には state（意識ないし生理 的レベル）に強い影響を受け，これを無視して vital signs を判断することはできないというこ とである。したがってモニタの瞬間的数值をそ のまま判断の根拠とすることはできず，ある一 定期閒のトレンドとして活用するときにこそ有 効である．NI C Uに执ける呼吸・心拍モ二タ リングの今後の課題ともいえよう.

2）警報の意味

モニタの警報は常に警報を発するものではな く, 機器の性能や設定状況によってはかえって N I C U の騒音の原因となる場合もある。鋭い 観察眼のもとで警報の意味を判断しなければ, 機械に振り回されるばかりか児の状態を誤って 判断してしまら恐れがある. 現段階では，モニ 夕を看護観察上の補助的手段として認識してお くことが賢明である。 